\title{
Association of Protein Z with Prediabetes and Type 2 Diabetes (Endocrinol Metab 2021;36:637-46, Yun-Ui Bae et al.)
}

\author{
Tiffany Pascreau ${ }^{1,2}$, Maia Tchikviladze ${ }^{3}$, Emilie Jolly ${ }^{1}$, Sara Zia-Chahabi ${ }^{1}$, Bertrand Lapergue ${ }^{3}$, Marc Vasse ${ }^{1,2}$ \\ ${ }^{1}$ Biology Department, Foch Hospital, Suresnes; ${ }^{2}$ UMR-S 1176, Le Kremlin-Bicêtre; ${ }^{3}$ Department of Stroke Center and \\ Diagnostic and Interventional Neuroradiology, Foch Hospital, Suresnes, France
}

We read with interest the paper of Bae et al. [1] suggesting that plasma levels of protein $\mathrm{Z}$ (PROZ), a vitamin $\mathrm{K}$ dependent factor [2] could be a marker for the early detection of prediabetes. Indeed, they observed lower levels of $\mathrm{PROZ}$ in patients with type 2 diabetes mellitus (T2DM) or in prediabetic patients, and suggested that a cut-off of $1,484 \mathrm{pg} / \mathrm{mL}$ and of $1,404 \mathrm{pg} / \mathrm{mL}$ PROZ could identify prediabetic and T2DM patients, respectively. As PROZ deficiency was previously identified as a risk factor for ischemic stroke [3,4], we systematically measure PROZ (Zymutest protein Z, Hyphen, Neuville sur Oise, France) in patients with proven ischemic stroke, as well as fasting glucose and hemoglobin A1c (HbA1c) by capillary electrophoresis (Sebia, Lisses, France). From November 2012 to June 2016, these parameters were available for 421 (171 females, 250 males, median age 51 years). Of them, 34 ( $8 \%$ ) were previously diagnosed with T2DM. We observed that median PROZ levels were similar between diabetic and in non-diabetic patients (2,295 and $1,958 \mathrm{pg} / \mathrm{mL}$, respectively; $P=0.209$ ). According to the French guidelines we also divided diabetic patients into two groups: patients with correct glycemic control ( $\mathrm{HbAlc}<7 \%$ ) and patients with uncontrolled diabetes (HbA1c $\geq 7 \%$ ). The median PROZ levels were similar between the two groups (2,270 and 2,330 pg/mL, $P=0.807)$. Considering the threshold of $1.404 \mathrm{pg} / \mathrm{mL}$ of PROZ proposed by Bae at al. [1] to discriminate diabetic from normoglycemic patients, 110 (26.1\%) patients from our series were classified as diabetics, nine of the 34 known diabetics $(26.5 \%)$ being correctly classified by this approach. Lastly, we studied PROZ variations according to the levels of $\mathrm{HbAlc}$ as defined by the American Diabetes Association [5]. As it can be seen in the Table 1, PROZ levels were significantly higher $(P<0.05)$ in diabetic than in normoglycemic patients. This was already described by Heeb et al. [4], who observed, unexpectedly, higher PROZ levels in diabetic patients with stroke than in stroke patients without T2DM. Therefore, both studies, on larger populations of patients, do not confirm the association of T2DM with PROZ deficiency, at least in patients with vascular complications. These conflicting results could be due to the large unusual Gaussian distribution of $\mathrm{PROZ}$ [2], requiring the inclusion of an elevated number of patients in order to avoid biased results.

\section{CONFLICTS OF INTEREST}

No potential conflict of interest relevant to this article was reported.
Received: 19 July 2021, Accepted: 28 July 2021

Corresponding author: Marc Vasse

Biology Department, Foch Hospital, 40 Rue Worth, Suresnes 92150, France

Tel: + 33-146252296, Fax: +33-146252422,

E-mail: m.vasse@hopital-foch.com
Copyright $\odot 2021$ Korean Endocrine Society

This is an Open Access article distributed under the terms of the Creative Commons Attribution Non-Commercial License (https://creativecommons.org/ licenses/by-nc/4.0/) which permits unrestricted non-commercial use, distribution, and reproduction in any medium, provided the original work is properly cited. 
Table 1. Variations of Median Plasma PROZ, FG, TG According to the HbA1c Level in Patients with a Previous Ischemic Stroke

\begin{tabular}{|c|c|c|c|c|}
\hline & No. & PROZ, pg/mL & $\mathrm{FG}, \mathrm{mmol} / \mathrm{L}$ & $\mathrm{TG}, \mathrm{mmol} / \mathrm{L}$ \\
\hline Normoglycemic $(\mathrm{HbA} 1 \mathrm{c}<5.7 \%)$ & 263 & $1,940(1.375-2.472)$ & $4.9(4.6-5.4)$ & $1.17(0.83-1.5)$ \\
\hline Prediabetes (HbA1c 5.7\%-6.5\%) & 122 & $2,129(1.294-2.815)$ & $5.6(4.9-6.1)^{\mathrm{a}}$ & $1.68(0.98-1.92)^{\mathrm{a}}$ \\
\hline Diabetes $(\mathrm{HbA} 1 \mathrm{c}>6.5 \%)$ & 36 & $2,234(1.497-3.133)^{\mathrm{b}}$ & $7.9(6.6-10.5)^{\mathrm{a}, \mathrm{c}}$ & $1.94(1.09-2.87)^{\mathrm{a}, \mathrm{d}}$ \\
\hline
\end{tabular}

Values are expressed as median (interquartile range).

PROZ, protein Z; FG, fasting glycemia; TG, triglyceride; HbAlc, hemoglobin A1c.

${ }^{\mathrm{a}} P<0.001$ vs. normoglycemic; ${ }^{\mathrm{b}} P<0.05$ vs. normoglycemic; ${ }^{\mathrm{c}} P<0.001$ diabetes vs. prediabetes; ${ }^{\mathrm{d}} P<0.05$ diabetes vs. prediabetes.

\section{ORCID}

Tiffany Pascreau https://orcid.org/0000-0003-1935-5402

Marc Vasse https://orcid.org/0000-0002-8784-7209

\section{REFERENCES}

1. Bae YU, You JH, Cho NH, Kim LE, Shim HM, Park JH, et al. Association of protein $\mathrm{Z}$ with prediabetes and type 2 diabetes. Endocrinol Metab (Seoul) 2021;36:637-46.

2. Miletich JP, Broze GJ Jr. Human plasma protein Z antigen: range in normal subjects and effect of warfarin therapy.
Blood 1987;69:1580-6.

3. Vasse M, Guegan-Massardier E, Borg JY, Woimant F, Soria C. Frequency of protein $\mathrm{Z}$ deficiency in patients with ischaemic stroke. Lancet 2001;357:933-4.

4. Heeb MJ, Paganini-Hill A, Griffin JH, Fisher M. Low protein $\mathrm{Z}$ levels and risk of ischemic stroke: differences by diabetic status and gender. Blood Cells Mol Dis 2002;29:13944.

5. American Diabetes Association. Diagnosis and classification of diabetes mellitus. Diabetes Care 2010;33 Suppl 1: S62-9. 